\title{
Urticaria and Angioedema: an Update on Classification and Pathogenesis
}

Radonjic-Hoesli, Susanne ; Hofmeier, Kathrin Scherer ; Micaletto, Sara ; Schmid-Grendelmeier, Peter ; Bircher, Andreas ; Simon, Dagmar

DOI: https://doi.org/10.1007/s12016-017-8628-1

Posted at the Zurich Open Repository and Archive, University of Zurich ZORA URL: https://doi.org/10.5167/uzh-139444

Journal Article

Accepted Version

Originally published at:

Radonjic-Hoesli, Susanne; Hofmeier, Kathrin Scherer; Micaletto, Sara; Schmid-Grendelmeier, Peter; Bircher, Andreas; Simon, Dagmar (2018). Urticaria and Angioedema: an Update on Classification and Pathogenesis. Clinical Reviews in Allergy Immunology, 54(1):88-101.

DOI: https://doi.org/10.1007/s12016-017-8628-1 


\title{
Urticaria and Angioedema: an Update on Classification and Pathogenesis
}

\author{
Susanne Radonjic-Hoesli ${ }^{1}$ \& Kathrin Scherer Hofmeier ${ }^{2}$ \& Sara Micaletto ${ }^{3}$ \& \\ Peter Schmid-Grendelmeier ${ }^{3}$ \& Andreas Bircher ${ }^{2}$ \& Dagmar Simon ${ }^{1}$
}

Published online: 26 July 2017

\begin{abstract}
Urticaria is a common, mast cell-driven disease presenting with wheals or angioedema or both. In the last years, urticaria has increasingly attracted notice to clinicians and researchers, last but not least inspired by the approval of omalizumab, an anti-IgE antibody, for urticaria treatment. There is wide consensus on the clinical classification based on duration and elicitation. However, the pathogenesis is incompletely understood. This review summarizes current guidelines for the management and novel insights in the pathogenesis of urticaria with special focus on their impact on clinical praxis. The classification of urticaria subgroups is mainly based on clinical criteria: acute and chronic urticaria (CU). Chronic urticaria comprises both chronic spontaneous urticaria (CSU) and chronic inducible urticaria (CIndU) that includes physical and non-physical urticarias. Recent research focused on characterizing the role of cells and mediators involved in the pathogenesis of urticaria, identifying the mechanisms of mast cell activation, and investigating underlying autoimmune processes in chronic spontaneous urticarial. Currently, non-sedating antihistamines and omalizumab, an antiimmunoglobulin E antibody, are recommended for the therapy of chronic urticaria, as both exhibit a favorable
\end{abstract}

* Susanne Radonjic-Hoesli

Susanne.radonjic@insel.ch

* Dagmar Simon

Dagmar.simon@insel.ch

1

Department of Dermatology, Inselspital, Bern University

Hospital,

University of Bern, 3010 Bern, Switzerland

2

Department of Dermatology, Allergy Unit, University Hospital

Basel, 4031 Basel, Switzerland

Department of Dermatology and Allergy, UniversityHospital Zurich, 8091 Zurich, Switzerland efficacy and safety profile. Novel therapeutic strategies aim at specifically targeting cells and mediators involved in the pathogenesis of urticaria.

Keywords Angioedema . Mastcell . Histamine . Omalizumab . Urticaria

$\begin{array}{ll}\text { Abbreviations } \\ \text { ACE } & \text { Angiotensin converting enzyme } \\ \text { ACU } & \text { Acquired cold urticaria } \\ \text { AE } & \text { Angioedema } \\ \text { AIU } & \text { Autoimmune urticaria } \\ \text { ASST } & \text { Autologous serum skin test } \\ \text { ChU } & \text { Cholinergic urticaria } \\ \text { CIndU } & \text { Chronic indicible urticaria } \\ \text { CRTH2 } & \text { Chemoattractant receptor-homologous } \\ & \text { molecule expressed on TH2 cells } \\ \text { CU } & \text { Chronic urticaria } \\ \text { CSU } & \text { Chronic spontaneous urticaria } \\ \text { DPU } & \text { Delayed pressure urticaria } \\ \text { Ig } & \text { Immunoglobuline } \\ \text { IL } & \text { Interleukin } \\ \text { PG } & \text { Prostaglandin } \\ \text { SU } & \text { Solar urticaria } \\ \text { TNF } & \text { Tumor necrosis factor }\end{array}$


TPO Thyroperoxidase

UAS Urticaria activity score

Urticaria is a common disease as in acute form affects $20 \%$ of the general population and chronic urticaria (CU) up to 5\% [1].Recent progress in the therapy ofchronic urticaria with the approval of omalizumab has extensively stimulated clinical and basic research in the field. In this review, we highlight novel insights in the pathogenesis and management of urticaria which we selected because of their potential impact on daily practice.

\section{Current Definitions}

Urticaria is defined as the sudden development of transient hives (wheals) and angioedema or both [2]. A wheal is characterized by a circumscribed superficial edema of the skin, mostly surrounded by a bright red erythema and associated with a strong itching or burning sensation. In urticaria, wheals develop within several minutes and have a transient nature inasmuch as the skin returns to its normal appearance within 1-24h.Angioedema presents aspainful orburning,non-itchy, and less well-demarcated edema of the deep dermis and subcutis, or mucous membranes. Usually, angioedema appears as skin-colored or slightly red swellings and, compared to wheals, they slowly develop and may persist for several days [2]. In addition to the skin and adjacent mucosa, the gut is typically affected by certain types of angioedema, e.g., hereditary angioedema. Angioedema of the pharynx or larynx may be life threatening through the risk of asphyxiation [3].

\section{Clinical Classification of Urticaria}

Current classifications consider both duration and causes/ triggers of urticaria [2,4]. Acute urticaria is defined by a repeated appearance of wheals with or without angioedema over a period of up to 6 weeks, whereas the recurrence of lesions over more than 6 weeks is considered as chronic [2]. In 10-20\% ofthe cases, angioedema may be the first and often only manifestation of urticaria. Approximately $60 \%$ of the patients with chronic spontaneous urticaria (CSU) report on angioedema episodes [5]. For a comprehensive review on the differential diagnosis of angioedema without urticaria, see a very recent review in this journal [3].

A recent study reported a high frequency of systemic signs and symptoms such as joint pain or swelling (55.3\%), headache/fatigue $(47.6 \%)$, flushing $(42.7 \%)$, wheezing or breathlessness $(30.1 \%)$, gastrointestinal complaints (26.2\%), and palpitations (9.7\%) in two thirds of adult patients with CSU that are probably under-recognized in daily practice [6]. Interestingly, the number of organs involved did not correlate with serum tryptase levels [6].

Depending on whether the skin lesions appear spontaneously or can be induced by a specific trigger, urticaria is classified as either CSU or chronic inducible urticaria (CIndUs) [2, 4]. Within the group of CIndUs, symptomatic dermographism/urticaria factitia, cold- and heat-induced urticarias, delayed pressure urticaria, solar urticaria, and vibratory angioedema are defined as physical urticarias. Non-physical CIndUs include cholinergic urticaria, contact urticaria, and aquagenic urticaria [4].

\section{Chronic Spontaneous Urticaria}

A nationwide epidemiological study revealed an annual prevalence of CSU ranging from $0.02 \%$ in 2002 to $0.38 \%$ in 2013 and an incidence of $0.10-1.50$ per 1000 personyears in Italy [7]. For both prevalence and incidence rates, female patients outnumbered males: 0.48 versus $0.23 \%$ and 1.6 versus 0.8 per 1000 person-years, respectively [7]. Obesity, anxiety, dissociative and somatoform disorders, and malignancies were associated with an increased risk to develop CSU [7]. Among patients with CSU, two thirds reacted to physical triggers [8]. CSU is considered a mast cell-driven disease triggered by infections, food or drug intolerance, activation of the coagulation cascade, genetic disposition, or autoimmunity [9]. Both type I (IgE mediated) and type II (autoantibodies of IgG or IgM type) hypersensitivity reactions have been associated with CSU [9]. The autologous serum skin test (ASST: intradermal injection of patients own serum) is often used as screening for autoimmune CSU since some studies found positive reactions morefrequently inCSU patientscomparedwith healthy controls, atopic individuals, or CIndUs [9]. In order to test the presence and functional activity of antiIgE and antiIgE receptor autoantibodies, additional diagnostic tests with ELISA or Western blot and basophil activation test have been recommended [10].

\section{Chronic Inducible Urticarias}

Symptomatic Dermographism

Urticarial dermographism is the most frequent form of physical urticaria with an estimated prevalence of $5 \%$ of the general population [11]. Symptomatic dermographism is an exaggerated response to a relatively minor stroking pressure, rubbing, or scratching, e.g., induced by trouser waistbands, cuffs, or collars [12]. Usually, the wheals disappear within minutes after cessation of the causative stimulus. Recently, an instrument for assessing provocation 
Delayed pressure urticaria (DPU) presents with angioedemalike swellings at areas of the skin and mucosa exposed to pressure. Classical wheals do not occur in DPU. threshold levels in patients with symptomatic dermographism has been developed (Fig. 1) [13].

\section{Acquired Cold Urticaria}

Acquired cold urticaria (ACU), the second most frequent type of physical urticaria, is characterized by lesions developing upon exposure to cold air, liquids, or solids and occurs more frequently in women than men [4, 14].

Fig. 1 Urticarial dermographism induced by a dermographometer on the back of patient (left) and a wheal provoked by cold exposure in a patient with acquired cold urticaria $\left(4{ }^{\circ} \mathrm{C}\right.$, right $)$

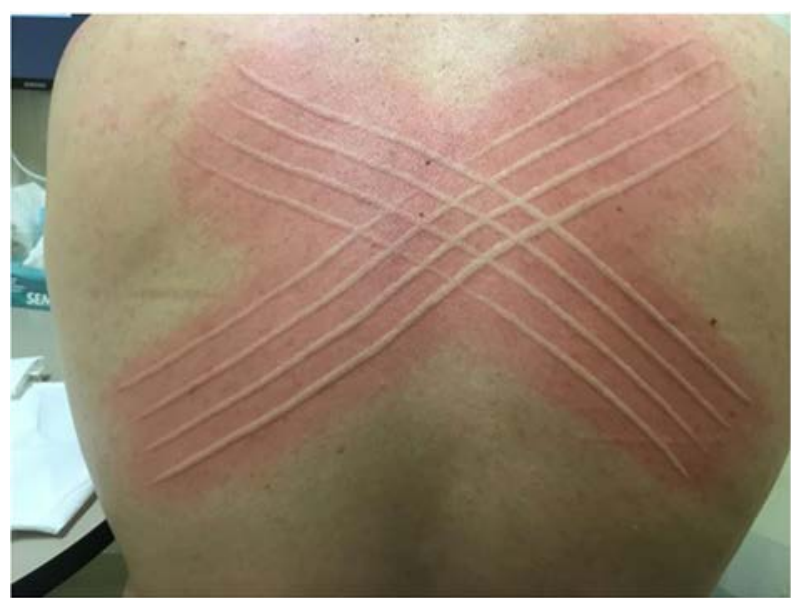

bra [18].

Solar Urticaria

Inmost patients with solar urticaria (SU), the trigger is a UV-A light, while provocation by visible or UV-B light is less frequent. SU is rare: $0.08 \%$ among urticaria patients, $2.3 \%$ of the patients with acute sun-induced skin problems. Female predominance, an association with atopy but not with skin pigmentation type as well as concomitant other types of CU have been reported in SU [19]. Upon activation by light, serum or dermal factors, that have not been further specified, have been assumed to cause mast cell degranulation [20]. Omalizumab may be helpful in some SU patients [21, 22].

\section{Cholinergic Urticaria}

Cholinergic urticaria $(\mathrm{ChU})$ is triggered by a sudden increase of body core temperature, e.g., induced by exercise/exertion, fever, hot baths or showers, emotional stress, hot or spicy foods, and drinks. Its prevalence is higher in young adults and peaks in winter in some patients $[23,24]$. Some authors found an association with atopy and bronchial hyperresponsiveness [23, 25, 26]. A distinct sign of $\mathrm{ChU}$ are extensive flares of short-lived, pruritic, tiny (up to 5-6 mm) wheals, so-called pinpoint wheals. Recent studies demonstrated a lack of acetylcholinesterase in eccrine gland epithelial cells and a decreased expression of the cholinergic receptor M3 (CHRM3), probably due to an autoimmune reaction to eccrine sweat glands and/or
Painful swellings, itching, or burning occur several hours
after exposure to vertical pressure and may persist for hours, sometimes longer than $24 \mathrm{~h}$. Triggers are carrying backpacks or bags with shoulder straps, sitting on hard chairs, tight shoes, carrying heavy bags by hand. DPU often coexists with CSU or other types of physical urticaria. DPU should be distinguished from symptomatic dermographism in which friction induces wheals without

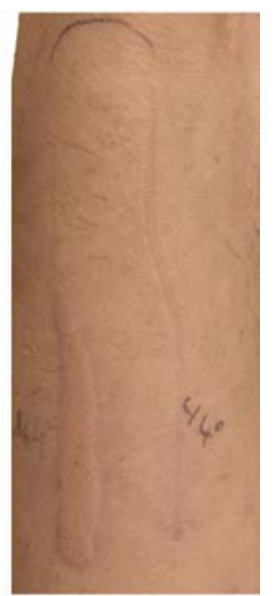

Extensive cold contact, e.g., diving in cold water, may Heat-Induced Urticaria

In heat urticaria, a very rare variant of physical urticaria, a wheals usually persist for $1-3 \mathrm{~h}$ [18].

\section{Delayed Pressure Urticaria}


acetylcholine receptors, resulting in increased tissue levels of acetylcholine that stimulates mast cells degranulation $[18,27]$. In addition to cholinergic agents, such as acetylcholine, histamine, allergenic components of sweat, serum factors, poral occlusion of eccrine sweat glands, and anhidrosis have been accused to induce ChU [28]. Japanese groups have suggested a ChU classification based on clinical characteristics: (1) conventional sweat allergy type, (2) follicular type with a positive ASST, (3) ChU with palpebral angioedema, and (4) $\mathrm{ChU}$ with acquiredanhidrosis and/or hypohidrosis [27-31].

Table 1 Differential diagnosis of atypical cold urticaria (modified from [17, 18])

\section{Vibratory Angioedema}

This extremely rare variant of physical urticaria typically presents with angioedema immediately developing after exposure to local vibration [18]. Vibratory angioedema induced by snoring or dental procedures has been observed $[32,33]$. Recently, a novel missense variant in ADGRE2 has been reported as the basis of autosomal dominant vibratory urticaria [34].

\section{Contact Urticaria}

Upon contact with the provoking substance, contact urticaria immediately manifests with wheals that disappear within a few hours. The wheals are provoked by either IgE-mediated or non-immunologic mechanisms. The urticarial reaction is usually confined to the area of exposure, but may spread and cause systemic symptoms, which might be life threatening in IgE-mediated allergic contact urticaria [35, 36]. Repeated contact with the causative substance may lead to the development of dermatitis/eczema, either by non-immunological/irritant or by IgE-mediated allergic reactions. Common eliciting factors include foods, plant components (esp. sap, leaves, etc.), latex, drugs, cosmetics, industrial chemicals, animal products, or textiles [37]. Thus, contact urticaria should be recognized as an occupational skin disease, e.g., in food processing workers, healthcare professionals, and hairdressers.
Aquagenic Urticaria

Aquagenic urticaria is a rare variant of CIndUs and shares features of both physical urticarial and contact urticaria. Patients exhibit folliculocentric wheals of 1-3 mm diameter and surrounding larger flares within 20-30 min after skin contact to water, sweat, or tears [38]. The shortlived wheals usually occur on the trunk and upper arms, while palms and soles are spared. Aquagenic urticaria has a high impact on the quality of life. Based on a recent comprehensive review, there are atypical clinical

\begin{tabular}{ll}
$\begin{array}{l}\text { Atypical acquired cold } \\
\text { urticaria }\end{array}$ & Cold contact stimulation test negative \\
$\begin{array}{l}\text { Delayed cold urticaria } \\
\text { Cold-dependent } \\
\text { dermographism }\end{array}$ & Wheals develop up to 24 h after testing \\
$\begin{array}{l}\text { Cold-induced cholinergic } \\
\text { urticaria }\end{array}$ & Induced upon stroking of precooled skin \\
$\begin{array}{l}\text { Systemic atypical cold } \\
\text { urticaria }\end{array}$ & $\begin{array}{c}\text { Wheals plus systemic signs and symptoms upon exposure to distinct } \\
\text { environmental cold conditions }\end{array}$ \\
\hline
\end{tabular}

presentations, with urticarial reactions depending on the salinity of the water, and exaggerated reactions in patients with associated systemic diseases or decreased thickness of the stratum corneum following epilation or exposure to organic solvents [38].

\section{Urticaria Impairs Quality of Life}

In acute urticaria, pruritus had the highest negative impact on the patients' quality of life [39]. Patients with acute urticaria were shown to be more satisfied with their lives and used emotion-focused coping and sought social support for emotional and instrumental reasons to a greater degree than patients with chronic urticaria [40]. A recent study on CU patients reported a mean total score of $36(0-$ 100) using the Chronic Urticaria Quality of Life Questionnaire [41]. The items with the highest mean scores were nervousness and sense of shame because of lesions [41]. In CU patients, mental health and physical impairment, activity levels on and off work as well as anxiety and depression were comparable with those of patients with moderate and severe psoriasis [42].

For the assessment of disease activity, the patients' healthrelated quality oflifeand the disease impactondaily activities, a number of detailed questionnaires have been developed [43-45]. For daily routine, the Urticaria Activity Score (UAS) 7 is recommended which assesses the number of wheals and itch intensity on seven consecutive days (maximum score per day: six; zero $=$ no symptoms, three $=$ 
severe symptoms) [43, 44]. The UAS7 might be amended by other disease activity parameters, e.g., the size of the largest wheal [45]. CU severity assessed by the UAS7 was shown to correlate with the impact on quality of life, sleep and daily activity interference, presence of angioedema, and diphenhydramine use [46].

\section{Diagnostic Procedures and Differential Diagnoses}

Current guidelinesof urticaria management recommend a lean diagnostic work-up that focuses on the examination of clinical signs and assessment of symptoms associated with

\section{Pathogenesis}

Although urticaria is a common disease, its pathogenesis is poorly understood. Current urticaria research focuses on three topics: (1) to characterize the cells and mediators involved, (2) to identify the mechanisms of mast cell activation, and (3) to investigate (auto)immune processes associated with CSU. Here, we will provide a selection of previous published work that might be important to our understanding of urticaria and developing novel therapeutic strategies.

Cells and Mediators Involved in Urticaria Pathogenesis

Redness, swelling, and itching of the pathognomonic
Fig. 2 Diagnostic work-up of urticaria with/without angioedema

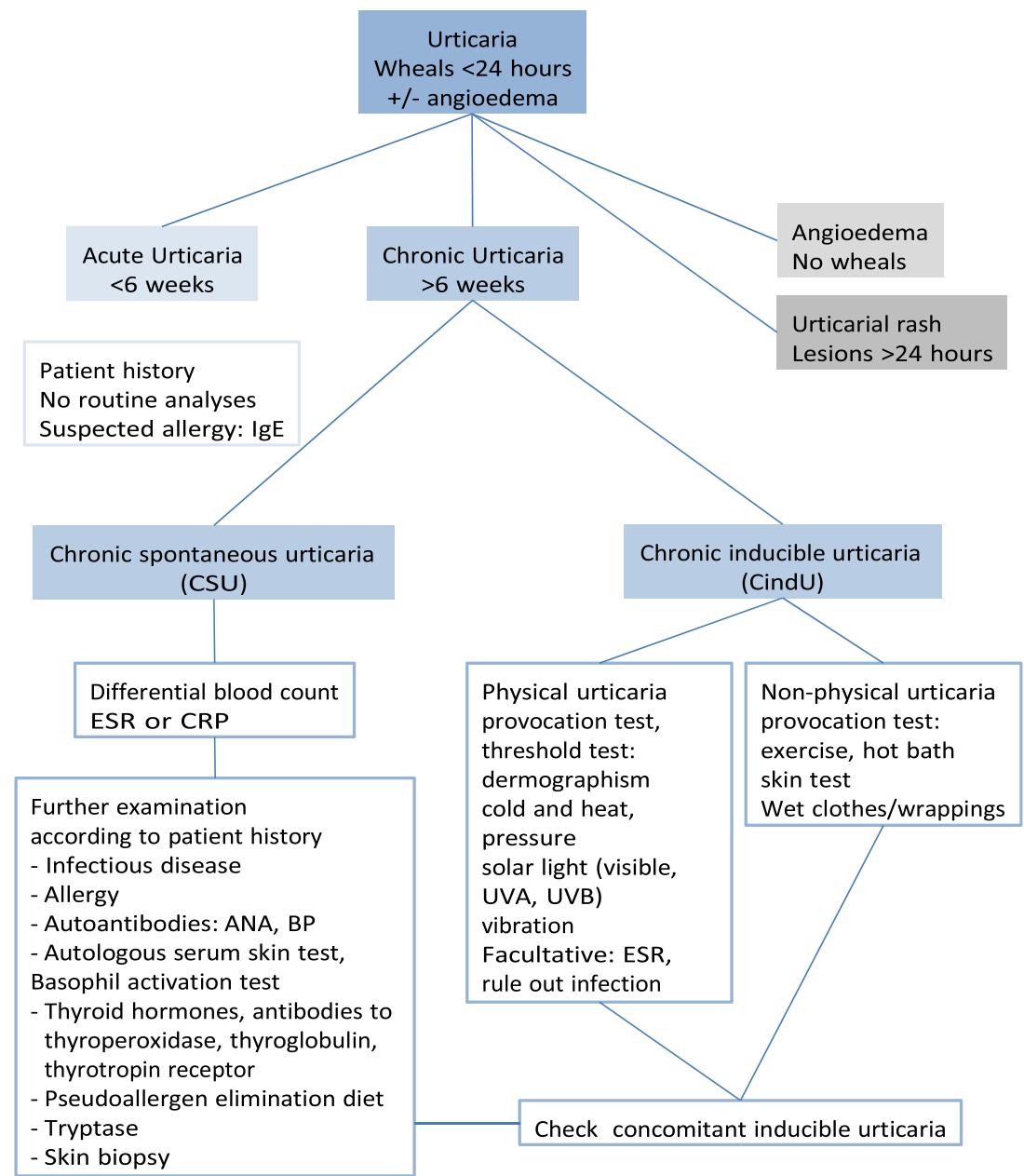

wheals are the clinical correlate of vasodilatation, increased vascular permeability with leakage of fluid into the tissue, and stimulation of sensory nerve endings resulting upon activation, degranulation, and release of vasoactive substances by dermal mast cells. Mast cells contain a multitude of electro-dense granules with preformed and preactivated mediators, including effector mediators such as histamine, cytokines, and chemokines [70]. Their release precedes the generation of arachidonic acid metabolites, e.g., prostaglandin D2 (PGD2) and 
leukotriene E4 (LTE4), and platelet activation factor (PAF) [71]. Among mediators synthesized by mast cell such as tumor necrosis factor (TNF)- $\alpha$, interleukin (IL)-1, IL-4, IL5, IL-6, IL-8, IL-16, CCL-2, CCL-3, and RANTES, transglutaminase (TG) 2 has been identified in the skin and peripheral blood of CSU patients [72]. These mediators

Table 2 Differential diagnoses of urticaria with/without angioedema may act as chemoattractants for eosinophils, neutrophils, and $\mathrm{T}$ cells. Indeed, urticaria skin harbors a mixed perivascular infiltrate consistent of monocytes, eosinophils, basophils, and mainly $\mathrm{CD} 4^{+} \mathrm{T}$ cells. Cytokines initiating $\mathrm{T}$ helper (Th) 2

\begin{tabular}{|c|c|c|c|c|}
\hline \multirow[t]{2}{*}{ Disease } & \multicolumn{2}{|c|}{ Skin, mucosa } & \multirow{2}{*}{$\begin{array}{l}\text { Other } \\
\text { organs } \\
\text { involved }\end{array}$} & \multirow[t]{2}{*}{ Comments, references } \\
\hline & $\begin{array}{l}\text { Urticarial } \\
\text { rash }\end{array}$ & Angioedema & & \\
\hline Urticaria vasculitis & + & & $(+)$ & $\begin{array}{l}{[47]} \\
\text { Wheal }>24 \text { h, } \\
\text { leukocytoklastic vasculitis }\end{array}$ \\
\hline $\begin{array}{l}\text { Normocomplementemic } \\
\text { Hypocomplimentemic }\end{array}$ & + & & + & [48] \\
\hline $\begin{array}{l}\text { Autoimmune diseases } \\
\text { Bullous pemphigoid }\end{array}$ & + & & - & $\begin{array}{l}\text { [49] } \\
\text { Autoantibodies to bullous } \\
\text { pemphigoid antigens } \\
\text { BP180, BP230 }\end{array}$ \\
\hline $\begin{array}{l}\text { Systemic lupus } \\
\text { erythematosus } \\
\quad \text { (SLE) }\end{array}$ & + & & + & $\begin{array}{l}{[50,51]} \\
\text { Antinuclear antibodies } \\
\text { (ANA), Increased risk of } \\
\text { SLE in CSU (14.6) }\end{array}$ \\
\hline $\begin{array}{l}\text { Autoinflammatory } \\
\text { diseases }\end{array}$ & + & $(+)$ & + & $\begin{array}{l}\text { [52-54] } \\
\text { Interleukin 1-mediated }\end{array}$ \\
\hline $\begin{array}{l}\text { Cryopyrin-associated } \\
\text { periodic } \\
\text { syndrome (CAPS) }\end{array}$ & + & & & $\begin{array}{l}\text { [55] } \\
\text { Cryopyrin NLRP3 gene } \\
\text { mutations }\end{array}$ \\
\hline $\begin{array}{l}\text { Familial cold } \\
\text { autoinflammatory } \\
\text { syndrome (FCAS) }\end{array}$ & + & & & $\begin{array}{l}\text { Cold urticaria, fever, } \\
\text { arthritis }\end{array}$ \\
\hline $\begin{array}{l}\text { Muckle-Wells syndrome } \\
\text { (MWS) }\end{array}$ & + & & & Deafness, amyloidosis \\
\hline $\begin{array}{l}\text { Chronic infantile } \\
\text { neurological, } \\
\text { cutaneous and articular } \\
\text { syndrome (CINCA) }\end{array}$ & + & & & $\begin{array}{l}\text { Polyarthritis, chronic } \\
\text { meningitis, fever }\end{array}$ \\
\hline Schnitzler syndrome & + & & & [56] \\
\hline & & & & $\begin{array}{l}\text { Monoclonal IgM } \\
\text { gammopathy }\end{array}$ \\
\hline Neutrophilic dermatoses & + & & $(+)$ & {$[57,58]$} \\
\hline & & & & $\begin{array}{l}\text { Peripheral blood and skin } \\
\text { neutrophilia }\end{array}$ \\
\hline Sweet syndrome & + & & & \\
\hline Eosinophilic dermatoses & & & & [59] \\
\hline & & & & $\begin{array}{l}\text { Skin eosinophilia, flame } \\
\text { figures }\end{array}$ \\
\hline Eosinophilic dermatitis & + & & & \\
\hline Wells' syndrome & + & & & \\
\hline Infectious/parasitic diseases & & & & \\
\hline Arthropod reactions & + & $(+)$ & & \\
\hline Viral exanthema & + & & $(+)$ & {$[60]$} \\
\hline
\end{tabular}




\begin{tabular}{|c|c|c|c|}
\hline Drug induced & & & {$[61]$} \\
\hline Beta-lactam-antibiotics & + & $(+)$ & IgE mediated \\
\hline NSAID & + & $(+)$ & COX-1 inhibitors \\
\hline Muscle relaxants & + & $(+)$ & \\
\hline Platin salts & + & $(+)$ & \\
\hline Taxans & + & $(+)$ & \\
\hline
\end{tabular}

Table 2 (continued)

\begin{tabular}{|c|c|c|c|}
\hline \multirow[t]{2}{*}{ Disease } & Skin, mucosa & \multirow{2}{*}{$\begin{array}{c}\text { O } \\
\text { Angioedema }\end{array}$} & \multirow[t]{2}{*}{ Comments, references } \\
\hline & $\begin{array}{c}\text { her organs Urticarial } \\
\text { involved rash }\end{array}$ & & \\
\hline $\begin{array}{l}\text { Polymorphic eruption of } \\
\text { pregnancy }\end{array}$ & + & & {$[62]$} \\
\hline \multirow[t]{2}{*}{ Angioedema } & + & & {$[63,64]$} \\
\hline & & & $\begin{array}{l}\text { Complement } \mathrm{C} 1 \text {-inhibitor } \\
\text { quantity or function and } \mathrm{C} 4 \\
\text { decreased }\end{array}$ \\
\hline Hereditary & + & + & $\begin{array}{l}\text { Angioedema of respiratory and } \\
\text { gastrointestinal tract }\end{array}$ \\
\hline Acquired & + & + & \\
\hline $\begin{array}{l}\text { Angiotensin-converting } \\
\text { enzyme (ACE) inhibi- } \\
\text { tors }\end{array}$ & + & + & Bradykinin mediated \\
\hline \multicolumn{4}{|l|}{$\begin{array}{l}\text { Angiotensin (AT) receptor } \\
\text { blockers }\end{array}$} \\
\hline \multirow[t]{2}{*}{ Anaphylaxis } & + & + & {$[65-67]$} \\
\hline & & & Specific $\operatorname{IgE}$ \\
\hline \multirow[t]{2}{*}{ Mastocytosis } & & & {$[68]$} \\
\hline & & & $\begin{array}{l}\text { Serum tryptase, skin, and bone } \\
\text { marrow biopsy }\end{array}$ \\
\hline Cutaneous & $(+)$ & - & \\
\hline Systemic & $(+)$ & + & \\
\hline
\end{tabular}

immune response such as IL-33, IL-25, and thymic stromal lymphopoietin (TSLP) along with IL-4 and IL-5 are present in lesional skin [73]. This observation together with previous reports on the expression of INF- $\gamma$ and TNF$\alpha$ [74] suggest a mixed Th2/Th1 immune response. Cholinergic urticaria was reported to be associated with a atopic predisposition in $57 \%$ of the patients, in whom high Erlangen atopy scores corresponding to a distinct atopic predisposition of the skin were linked to high severity and impact on quality of life [75]. Several other mediators such as vascular endothelial growth factor, matrix metalloproteinase-9, and IL-6 have been found to be elevated in the peripheral blood of CSU patients [76-78].
However, whether these phenomena are specific or part of a general inflammatory milieu needs to be investigated.

Recent research hasfocused on a role ofbasophils in urticaria. Both peripheral blood basopenia and altered basophil FceRI function have been documented in $\mathrm{CU}$ patients [79]. Interval improvements of disease severity in CSU patients were associated with increased basophil numbers and IgE-mediated histamine release [80]. The reduced expression of the chemoattractant receptorhomologous molecule expressed on TH2 cells (CRTH2) on basophils and eosinophils in CSU patients compared with healthy controls has been assumed a result of an ongoing PGD2 stimulation [81]. In the sera of CSU patients, increased IL-31 levels have been detected. IL-31 is 
released by basophils and may stimulate basophil chemotaxis and activate IL-4 and IL-13 release [82]. The increased expression of CD63 on basophils found in CSU patients correlated with allergic sensitization, serum autoreactivity, and basophil reactivity [83]. Interestingly, a paradoxic downregulation of FceRI/anti-FceRI/ anti-IgE triggered histamine release from basophils has been documented in CU patients [84]. Serum of patients with active CSU was shown to suppress basophil FceRI activity, even when $\operatorname{IgE}$ and $\operatorname{IgG}$ were depleted [85]. Whether the alterations of basophils in urticaria are pathogenic or secondary events is currently under investigation.

In CSU patients, eosinophilia has been observed in lesional skin and may persist in non-lesional skin. This observation, together with microvascular changes and increased mast cell numbers, suggests that non-lesional skin is primed for further whealing [86]. Both major basic protein and eosinophil peroxidase may induce histamine release from human mast cells [87]. A further role of eosinophils in $\mathrm{CU}$ has been proposed in the activation of the coagulation system due to their tissue factor expression [88].

\section{Mast Cell Activation}

In up to $40 \%$ of the patients with CSU, autoantibodies directed against the $\alpha$-chain of the high affinity $\operatorname{IgE}$ receptor (FceRI) and/ or IgE of the complement fixing subtypes IgG1 and IgG3 have been found [89]. Autoantibodies binding to their target results in complement activation, subsequent C5a formation that binds to the C5a receptor on mast cells leading to their activation and degranulation [90]. Since a diagnostic test measuring functionally active autoantibodies has not yet been made available, the diagnosis of autoimmune urticaria (AIU) is still obscure [9]. Interestingly, chemokines such as CCL17, CCL26, and CCL27 were significantly increased in patients with AIU in comparison to other forms of CU and correlated with disease severity [91].

Insights in the intracellular signal transduction pathways might elucidate new therapeutic targets. Recently, it has been shown that upon an activation of the $\beta$ - and $\gamma$-chain of the FceRI, immunoreceptor tyrosine-based activation motifs (ITAMs) are phosphorylated, which associate with Srcfamily protein tyrosine kinases, such as Syk. The deactivation is regulated by signal regulatory proteins containing inhibitory motifs (ITIMs) that recruit SHIP 1 and 2 which dephosphorylate the ITAMs [84]. In CU, altered levels of SHIP 1 and SHIP2 have been found [92]. In patients with non-steroidal antiinflammatory drug
(NSAID)-induced urticaria/angioedema, significant associations of polymorphisms in three key genes, involved in mast cell activation including Syk, have been observed [93].

The coagulation cascade is activated in CSU and involves both the extrinsic and intrinsic pathways [94-96]. Tissue factor over-expressed by eosinophils that are activated via $\mathrm{CD} 23$, the low affinity IgE receptor, has been identified as a trigger $[88,97]$. Sera from $\mathrm{CU}$ patients have been demonstrated to activate mast cell degranulation in an IgE- and IgG-independent manner and to increase vascular permeability [98]. However, the identity and function of these serum factors need yet to be identified. Interestingly, PAF may induce whealand-flare reactions independent of histamine release and mast cell degranulation [99].

Association of Urticaria with Autoimmunity and Infection

There is increasing evidence that autoimmunity plays a causative role in CSU [9]. Type I (IgE-autoantibodies to autoantigens, e.g., thyroperoxidase (TPO)) and type II (IgG-autoantibodies to IgE or FceRI) autoimmunity seem to be relevant in distinct CSU subpopulations rather than the same patients. Arguments supporting this concept are (1) the identification of two distinct subgroups with either low or high titers of anti-TPO IgE-antibodies (IgEanti$\mathrm{TPO}^{\text {low }}$ and IgE-anti-TPO ${ }^{\text {high }}$ ), (2) the absence of a correlation between IgE-autoantibodies and ASST response, (3) the correlation of IgG- but not IgEautoantibodies with disease activity/severity, and (4) different tempi of response to omalizumab [9]. In cholinergic urticaria, a hypersensitivity to sweat substances leaking from syringeal ducts to the dermis as well as an activation of mast cells by acetylcholine that is released by nerve cells but may not bind to its receptor because of reduced expression are discussed as main pathogenic mechanisms [100].

A recent meta-analysis confirmed the association of $\mathrm{CU}$ with thyroid autoimmunity reporting a higher prevalence of positive thyroid autoantibodies in patients with urticaria than non-urticaria controls (OR 6.55) [101]. The presence of anti-TPO-IgE is found in up to $54 \%$ of the CU patients [102], and a recent study suggested an autoallergic mast cell activation by anti-TPO-IgE [103].

The role of Helicobacter pylori (Hp) in CSU has controversially been discussed. Currently, it seems obvious that the prevalence of $\mathrm{Hp}$ infection is not increased in CSU patients, the effect of standard CSU treatment does not depend on Hp status, and Hp eradication does not have any additional beneficial effect on CSU [104]. A recent study 
showed an association with previous HHV-6 infection, persistent viral gene expression, and replication with CSU [105]. A systematic review on internal parasites revealed that CSU patients were more often diagnosed with protozoa, e.g., Blastocystis hominis, and had a significantly higher risk of Toxocara seropositivity and Anisakis simplex sensitization as compared to healthy controls [106].

\section{Therapy}

Guidelines for Urticaria Management

According to current recommendations, the aim is a complete symptom control as safe as possible [2]. All factors identified to trigger urticaria in a certain individual should be avoided. As first-line therapy, secondgeneration, non-sedating H1-antihistamines are used. Dose escalation up to fourfold dosage of antihistamines serves as second-line strategy. In case symptoms persist, an add-on of omalizumab, ciclosporin, or montelukast is recommended [2]. The American guidelines on urticaria management slightly differ from the European treatment standards [1]. Here, we will discuss new aspects in the management of urticaria and novel approaches. Use of Non-Sedating Antihistamines

Antihistamines act as inverse agonist of the histamine (H) 1 receptor and thus stabilize its inactive conformation [107]. Antihistamines may be up-dosed fourfold to the recommended standard dose. A questionnaire-based analysis revealed that patients who had up-dosed antihistamines reported a significant added benefit from taking two to four tablets daily while the number of reports of unwanted effects and sedation following updosing was not significantly different from those reported for standard doses [108]. In patients with cold contact urticaria, updosing of bilastine resulted in a significantly better effectiveness without evidence of increased sedation with dose escalation [109]. Since sedating antihistamines added on to second generation antihistamines had no additional effects on CSU, but significantly increased daytime somnolence, they are not recommended for urticaria therapy anymore [110]. Treatment of Children with Urticaria

Analogous to the adult patients, the same first-line therapy and up-dosing of non-sedating second generation antihistamines (weight adjusted) should be applied in children (2). Preferably, substances with proven efficacy and safety, e.g., cetirizine, desloratadine, and fexofenadine, should be used (2). Further steps have to be considered on an individual basis (2).

Omalizumab

The anti-IgE antibody omalizumab has been proven an efficacious and a well-tolerated therapy in patients with CSU refractory to antihistamines [111]. Recent publications also show its efficacy and safety in CIndUs, even though randomized controlled trials are still lacking $[112,113]$. So far, the mechanisms of action of omalizumab are not fully understood. A recent review summarized potential mechanisms that include reducing mast cell activation, reversing basopenia, and improving basophil IgE receptor function, reducing the activity of IgG autoantibodies against FceRI and IgE, of IgEautoantibodies against an antigen or autoantigen as well as of intrinsically Babnormal^ ${ }^{\wedge}$ IgE, and decreasing coagulation abnormalities associated with disease activity $[10,79]$. Omalizumab $300 \mathrm{mg}$ every 4 weeks achieves fast responses and sustained effects [114] and significantly reduces the incidence of angioedema [115]. Patients with positive basophil histamine release assay and ASST tend to have a slow response to omalizumab therapy suggesting that omalizumab acts via reducing FceRI expression [116]. An omalizumab treatment for 6 months might not be sufficient to control the disease [117]. Of note, retreatment of patients with CSU and/or CIndUs who initially responded to omalizumab, and experienced a relapse after suspending it, is considered as effective and safe as first treatment [118]. In case of a long-term therapy being required, a reduction of omalizumab dosage to $150 \mathrm{mg}$ and/or extension of application interval is recommended [119].

Ciclosporin

Ciclosporin is known to reduce the histamine release of both mast cells and basophils and affect Tcell activity. Based on the evidence of several randomized controlled trials, it is recommended as a third-line therapy [2]. Because of their better efficacy, ciclosporin and omalizumab have been favored over montelukast [120]. However, the safety profile of omalizumab was superior to that of other systemic therapies for urticaria including ciclosporin [121]. 
Table 3 Novel approaches for the treatment of urticaria

\begin{tabular}{|c|c|c|c|c|}
\hline Target & Drug name & Mechanism & Phase & $\begin{array}{l}\text { ClinicalTrials. } \\
\text { gov }\end{array}$ \\
\hline \multirow[t]{2}{*}{$\operatorname{IgE}$} & Ligelizumab & $\begin{array}{l}\text { Humanized monoclonal antibody targeting C } \varepsilon 3 \\
\text { domain of IgE [124] }\end{array}$ & $\begin{array}{c}\text { Phase } \\
2 b\end{array}$ & NCT02477332 \\
\hline & Quilizumab & $\begin{array}{l}\text { Humanized monoclonal antibody targeting } \\
\text { M1-prime segment of membrane bound IgE on } \\
\text { IgE-switched B cells, IgE memory B cells and } \\
\text { plasmablasts [125] }\end{array}$ & $\begin{array}{c}\text { Phase } \\
2\end{array}$ & NCT01987947 \\
\hline Syk & GSK2646264 & Potent and selective topical Syk inhibitor [123] & $\begin{array}{c}\text { Phase } \\
1\end{array}$ & NCT02424799 \\
\hline CRTh2 & AZD1981 & CRTh2 antagonist [123] & $\begin{array}{c}\text { Phase } \\
2 \mathrm{a}\end{array}$ & NCT02031679 \\
\hline \multirow[t]{2}{*}{ IL-1 $\beta$} & Canakinumab & Human monoclonal anti-IL $1 \beta$ antibody [126] & $\begin{array}{c}\text { Phase } \\
2\end{array}$ & NCT01635127 \\
\hline & Rilonacept & $\begin{array}{l}\text { Dimeric fusion protein composed of ligand binding } \\
\text { domain of IL-1 receptor and IL-1R accessory } \\
\text { protein bound to IgG1 [126] }\end{array}$ & $\begin{array}{c}\text { Phase } \\
2\end{array}$ & NCT02171416 \\
\hline $\begin{array}{l}\text { Vitamin } \\
\text { D3 }\end{array}$ & & $\begin{array}{l}\text { Supplementation because of reduced vitamin D } \\
\text { levels in CU patients [127] }\end{array}$ & $\begin{array}{c}\text { Phase } \\
3\end{array}$ & NCT02873364 \\
\hline
\end{tabular}

Inhibition of Tumor Necrosis Factor- $\alpha$

Currently registered clinical trials for urticaria therapy are given in Table 3.

Increased levels of TNF- $\alpha$ in skin samples of CU are the rational for the use of anti-TNF- $\alpha$ therapy in histamineresistant $\mathrm{CU}$. A single center retrospective observational study reported that upon therapy with TNF- $\alpha$ inhibitors, a total of 15 of $25(60 \%)$ patients with refractory $\mathrm{CU}$ achieved a complete or almost complete resolution of symptoms [122].

Novel Therapeutic Approaches

Recent research has improved our understanding of the pathogenesis of urticaria, in particular about the cells and mediators involved, signaling pathways, triggers, and associated autoimmune and infectious phenomena. Thus, a broad spectrum of potential therapeutic targets has been identified. The most promising recent strategies have been summarized

[123]:

- The development of more efficient antibodies targeting $\operatorname{IgE}$ and $\operatorname{IgE}$ receptor

- Blocking the recruitment and activation of inflammatory cells

- Inhibiting mast cell activation by blocking signaling pathways

- Blocking pro-inflammatory cytokines and neuropeptides

- Targeting complement C5a and C5a receptor

- Supplementing vitamin D

\section{Outlook}

As this review demonstrates, immense progress has been made in understanding the pathogenesis and management of urticaria over the last decade. The launch of omalizumab has not only fundamentally improved urticaria treatment, it has also stimulated research in the field. So far, the causes and mechanisms of mast cell activation in urticaria patients have not completely been understood. Expanding our knowledge on urticaria pathogenesis, its genetics and phenotypes will have a direct impact on clinical praxis toward a personalized medicine and the development of novel therapies.

Compliance with Ethical Standards

Conflict of Interest The authors declare that they have no conflict of interest.

Funding None.

Research Involving Human Participants and/or Animals Not applicable.

Ethical Approval and Informed Consent Not applicable. 


\section{References}

1. Fine LM, Bernstein JA (2016) Guideline of chronic urticaria beyond. Allergy Asthma Immunol Res 8:396-403. doi:10.4168/aair. 2016.8.5.396

2. Zuberbier $\mathrm{T}$, Aberer $\mathrm{W}$, Asero $\mathrm{R}$, Bindslev-Jensen $\mathrm{C}$ et al (2014) The EAACI/GA2LEN/EDF/WAO Guideline for the definition, classification, diagnosis, and management of urticaria: the 2013 revision and update. Allergy 69:868-887. doi:10.1111/all.12313

3. Wu MA, Perego F, Zanichelli A et al (2016) Angioedema phenotypes: disease expression and classification. Clinic Rev Allerg Immunol 51:162. doi:10.1007/s12016-016-8541-Z

4. Magerl M, Altrichter S, Borzova E, Giménez-Arnau A, Grattan CE, Lawlor F, Mathelier-Fusade P, Meshkova RY, Zuberbier T, Metz M, Maurer M (2016) The definition, diagnostic testing, and management of chronic inducible urticarias - the EAACI/GA(2) LEN/EDF/UNEV consensus recommendations 2016 update and revision. Allergy 71:780802. doi:10.1111/all.12884

5. Weller K, Maurer M, Grattan C, Nakonechna A, Abuzakouk M, Bérard F, Sussman G, Giménez-Arnau AM, Ortiz de Frutos J, Knulst A, Canonica GW, Hollis K, McBride D, Balp MM (2015) ASSURE-CSU: a real-world study of burden of disease in patients with symptomatic chronic spontaneous urticaria. Clin Transl Allergy 5:29. doi:10.1186/s13601-0150072-9

6. Doong JC, Chichester K, Oliver ET, Schwartz LB, Saini SS

(2017) Chronic idiopathic urticaria: systemic complaints and their relationship with disease and immune measures. J Allergy Clin Immunol Pract Epub ahead of print doi. doi:10.1016/j.jaip.2016.

11.037

7. Lapi F, Cassano N, Pegoraro V, Cataldo N, Heiman F, Cricelli I, Levi M, Colombo D, Zagni E, Cricelli C, Vena GA (2016) Epidemiology of chronic spontaneous urticaria: results from a nationwide, population-based study in Italy. Br J Dermatol 174: 996-1004. doi:10.1111/bjd.14470

8. Sánchez J, Amaya E, Acevedo A, Celis A, Caraballo D, Cardona R (2017) Prevalence of inducible urticaria in patients with chronic spontaneous urticaria: associated risk factors. $\mathrm{J}$ Allergy Clin Immunol Pract 5:464-470. doi:10.1016/j.jaip.2016.09.029

9. Kolkhir P, Church MK, Weller K, Metz M, Schmetzer O, Maurer M (2016) Autoimmune chronic spontaneous urticaria: what we know and what we do not know. J Allergy Clin Immunol Epub

ahead of print doi. doi:10.1016/j.jaci.2016.08.050

10. Konstantinou GN, Asero R, Ferrer M, Knol EF, Maurer M, Raap U, Schmid-Grendelmeier P, Skov PS, Grattan CE (2013) EAACI taskforce position paper: evidence for autoimmune urticaria and proposal for defining diagnostic criteria. Allergy 68:27-36. doi: 10.1111/all.12056

11. Dice JP (2004) Physical urticaria. Immunol Allergy Clin N Am 24:225-246

12. Taĺkapan O, Harmanyeri Y (2006) Evaluation of patients with symptomatic dermographism. JEADV 20:58-62

13. Mlynek A, Vieira dos Santos R, Ardelean E, Weller K, Magerl M, Church MK, Maurer M (2013) A novel, simple, validated and reproducible instrument for assessing provocation threshold levels in patients with symptomatic dermographism. Clin Exp Dermatol 38:360-366. doi:10.1111/ced.12107

14. Martinez-Escala ME, Curto-Barredo L, Carnero L, Pujol RM, Gimenez-Arnau AM (2015) Temperature thresholds in assessment of the clinical course of acquired cold contact urticaria: a retrospective observational one year study. Acta Derm Venereol 95:278-282. doi:10.2340/00015555-1918

15. Alangari AA, Twarog FJ, Shih $\mathrm{MC}$ et al (2004) Clinical features and anaphylaxis in children with cold urticaria. Pediatrics 113: e313-e317

16. Siebenhaar F, Weller K, Mlynek A, Magerl M, Altrichter S, Vieira dos Santos R, Maurer M, Zuberbier T (2007) Acquired cold urticaria: clinical picture and update on diagnosis and treatment. Clin Exp Dermatol 32:241-245

17. Wanderer AA, HoffmanHM (2004) Thespectrumof acquired and familial cold induced urticaria/urticaria-like syndromes. Immunol Allergy Clin N Am 24:259-286

18. Abajian M, Schoepke N, Altrichter S, Zuberbier T, Maurer M (2014) Physical urticarias and cholinergic urticaria. Immunol Allergy Clin N Am 34:73-88. doi:10.1016/j.iac.2013.09.010

19. Du-Thanh A, Debu A, Lalheve P et al (2013) Solar urticaria: a time-extended retrospective series of 61 patients and review of literature. Eur J Dermatol 23:202-207. doi:10.1684/ejd.2013. 1933

20. Horio $\mathrm{T}$ (1978) Photoallergic urticaria induced by visible light. Additional cases and further studies. Arch Dermatol 114:1761- 1764

21. Duchini G, Baumler W, Bircher AJ, Scherer K (2011) Failure of omalizumab (Xolairß) in the treatment of a case of solar urticaria caused by ultraviolet $\mathrm{A}$ and visible light. Photodermatol Photoimmunol Photomed 27:336-337. doi:10.1111/j.1600-0781. 2011.00624.x

22. Terrani I, Bircher AJ, Scherer Hofmeier K (2016) Solar urticaria induced by visible light: successful treatment with omalizumab. Clin Exp Dermatol 41:890-892. doi:10.1111/ced.12951

23. Zuberbier T, Althaus C, Chatraine-Hess S et al (1994) Prevalence of cholinergic urticaria in young adults. J Am Acad Dermatol 31: 978-981

24. Ramam M, Pahwa P (2012) Is cholincergic urticaria a seasonal disorder in some patients? Indian J Dermatol Venereol Leprol 78: 190-191. doi:10.4103/0378-6323.93641

25. Takahagi S, Tanaka T, Ishii K et al (2009) Sweat antigen induces histamine release form basophils of patients with cholinergic uticaria associated with atopic diathesis. $\mathrm{Br} \mathrm{J}$ Dermatol 160:426- 428 doi:10.1111/j.13652133.2008.08862.x

26. Petalas K, Kontou-Fili K, Gratziou C (2009) Bronchial hyperresponsiveness in patients with cholinergic urticaria. Ann Allergy Asthma Immunol 102:416-421. doi:10.1016/S10811206(10)60514-5

27. Sawada Y, Nakamura M, Bito T, Sakabe J, Kabashima-Kubo R, Hino R, Kobayashi M, Tokura Y (2014) Decreased expression of acetylcholine esterase in cholinergic urticaria with hypohidrosis or anhidrosis. J Invest Dermatol 134:276279. doi:10.1038/jid.2013. 244

28. Fukunaga A, Washio K, Hatakeyama M, Oda Y, Ogura K, Horikawa T, Nishigori C (2017) Cholinergic urticaria: epidemiology, physiopathology, new categorization, and management. Clin Auton Res Epub ahead of print doi. doi:10.1007/s10286-0170418-6 
29. Horikawa T, Fukunaga A, Nishigori C (2009) New concepts of hive formation in cholinergic urticaria. Curr Allergy Asthma Rep 9:273-279

30. Bito T, Sawada Y, Tokura Y (2012) Pathogenesis of cholinergic urticaria in relation to sweating. Allergol Int 61:539-544. doi:10. 2332/allergolint.12-RAI-0485

31. Fukunaga A, Hatakeyama M, Tsujimoto M, Oda Y, Washio K, Nishigori C (2015) Steroid treatment can improve the impaired quality of life of patients with acquired idiopathic generalized anhidrosis. $\mathrm{Br} \mathrm{J}$ Dermatol 172:537-538. doi:10.1111/bjd.13285

32. Kalathoor I (2015) Snoring-induced vibratory angioedema. Am J Case Rep 16:700-702. doi: 10.12659/AJCR.894636

33. Aloyouny A, Stoopler ET (2016) Vibrational angioedema: considerations for oral health care providers. Spec Care Dentist 36:335- 338. doi:10.1111/scd.12185

34. Boyden SE, Desai A, Cruse G, Young ML, Bolan HC, Scott LM, Eisch AR, Long RD, Lee CC, Satorius CL, Pakstis AJ, Olivera A, Mullikin JC, Chouery E, Mégarbané A, MedlejHashim M, Kidd KK, Kastner DL, Metcalfe DD, Komarow HD (2016) Vibratory urticaria associated with a missense variant in ADGRE2. N Engl J

Med 374:656-663. doi:10.1056/NEJMc1604757

35. Zuberbier T (2003) Urticaria. Allergy 58:1224-1234

36. Wedi B, Kapp A (2006) Current position of the role of allergic and non-allergic food hypersensitivity in urticaria. Hautarzt 57:101- 107

37. Williams JD, Lee AY, Matheson MC, Frowen KE, Moonan AM, Nixon RL (2008) Occupational contact urticaria: Australian data. Br J Dermatol 159:125-131. doi:10.1111/j. 1365-2133.2008.08583.x

38. Rothbaum R, McGee JS (2016) Aquagenic urticaria: diagnostic and management challenges. J Asthma Allergy 9:209-213

39. Kulthanan K, Chiawsirikajorn Y, Jiamton S (2008) Acute urticaria: etiologies, clinical course and quality of life. Asian Pac J Allergy Immunol 26:1-9

40. Zelić SB, Rubeša G, Brajac I, Peitl MV, Pavlović E (2016) Satisfaction with life and coping skills in the acute and chronic urticaria. Psychiatr Danub 28:34-38

41. Dias GA, Pires GV, Valle SO, Dortas SD Júnior, Levy S, França AT, Baiardini I, Canonica WG (2016) Impact of chronic urticaria on the quality of life of patients followed up at a university hospital. An BrasDermatol 91:754759.doi:10.1590/abd1806-4841. 20165071

42. Mendelson MH, Bernstein JA, Gabriel A, Balp MM, Tian H, Vietri J, Lebwohl M (2016) Patient-reported impact of chronic urticaria compared with psoriasis in the United States. J Dermatol Treat Epub ahead of print. doi:10.1080/09546634. 2016.1227421

43. Mlynek A, Zalewska-Janowska A, Martus P, Staubach P, Zuberbier T, Maurer M (2008) How to assess disease activity in patients with chronic urticaria? Allergy 63:777-780. doi:10.1111/ j.1398-9995.2008.01726.x

44. Baiardini I, Braido F, Bindslev-Jensen C, Bousquet PJ et al (2011) Recommendations for assessing patient-reported outcomes and health-related quality of life in patients with urticaria: a GA2LEN taskforce position paper. Allergy 66:840-844. doi:10. 1111/j.1398-9995.2011.02580.x

45. Mathias SD, Dreskin SC, Kaplan A, Saini SS, Spector S, Rosen KE (2010) Development of a daily diary for patients with chronic idiopathic urticaria. Ann Allergy Asthma Immunol 105:142-148. doi:10.1016/j.anai.2010.06.011

46. Stull D, McBride D, Tian H, Gimenez Arnau A, Maurer M, Marsland A, Balp MM, Khalil S, Grattan C (2017) Analysis of disease activity categories in chronic spontaneous/idiopathic urticaria. Br J Dermatol Epub ahead of print. doi:10.1111/bjd.15454

47. Staubach P (2007) Differential diagnosis of urticaria. Hautarzt 58: $314-317$

48. Jachiet M, Flageul B, Deroux A, Le Quellec A, Maurier F, Cordoliani F, Godmer P, Abasq C, Astudillo L, Belenotti P, Bessis D, Bigot A, Doutre MS, Ebbo M, Guichard I, Hachulla E, Héron E, Jeudy G, Jourde-Chiche N, Jullien D, Lavigne C, Machet L, Macher MA, Martel C, Melboucy-Belkhir S, Morice C, Petit A, Simorre B, Zenone T, Bouillet L, Bagot M, FrémeauxBacchi V, Guillevin L, Mouthon L, Dupin N, Aractingi S, Terrier B, French Vasculitis Study Group (2015) The clinical spectrum and therapeutic management of hypocomplementemic urticarial vasculitis: data from a French nationwide study of fifty-seven patients. Arthritis Rheumatol 67:527-534. doi:10.1002/art.38956

49. Feliciani C, Joly P, Jonkman MF, Zambruno G, Zillikens D, Ioannides D, Kowalewski C, Jedlickova H, Kárpáti S, Marinovic B, Mimouni D, Uzun S, Yayli S, Hertl M, Borradori L (2015) Management of bullous pemphigoid: the European Dermatology Forum consensus in collaboration with the European Academy of Dermatology and Venereology. $\mathrm{Br} \quad \mathrm{J}$ Dermatol 172:867-877. doi:10.1111/bjd.13717

50. Kolkhir P, Pogorelov D, Olisova O, Maurer M (2016) Comorbidity and pathogenic links of chronic spontaneous urticaria and systemic lupus erythematosus-a systematic review. Clin Exp Allergy 46:275-287. doi:10.1111/cea.12673

51. Confino-Cohen R, Chodick G, Shalev V, Leshno M, Kimhi O, Goldberg A (2012) Chronic urticaria and autoimmunity: associations found in a large population study. J Allergy Clin Immunol 129:1307-1313. doi:10.1016/j.jaci.2012.01.043

52. Wekell P, Karlsson A, Berg S, Fasth A (2016) Review of autoinflammatory diseases, with a special focus on periodic fever, aphthous stomatitis, pharyngitis and cervical adenitis syndrome. Acta Paediatr 105:1140-1151. doi:10.1111/apa.13531

53. Kastner DL, Aksentijevich I, Goldbach-Mansky R (2010) Autoinflammatory disease reloaded: a clinical perspective. Cell 140:784-790. doi:10.1016/j.cell.2010.03.002

54. Krause K, Grattan CE, Bindslev-Jensen C, Gattorno M, Kallinich T, de Koning HD, Lachmann HJ, Lipsker D, Navarini AA, Simon A, Traidl-Hoffmann C, Maurer M (2012) How not to miss autoinflammatory diseases masquerading as urticaria. Allergy 67:1465-1474. doi:10.1111/all.12030

55. Kuemmerle-Deschner JB, Ozen S, Tyrrell PN, et al. (2016) Diagnostic criteria for cryopyrin-associated periodic syndrome (CAPS) Ann Rheum Dis. Oct 4. doi: 10.1136/annrheumdis2016-209686

56. Gusdorf L, Asli B, Barbarot S, Néel A, Masseau A, Puéchal X, Gottenberg JE, Grateau G, Blanchard-Delaunay C, Rizzi R, Lifermann F, Kyndt X, Aubin F, Bessis D, Boye T, Gayet S, Rongioletti F, Sauleau E, Fermand JP, Lipsker D (2017) Schnitzler syndrome: validation and applicability of diagnostic criteria in real-life patients. Allergy 72:177-182. doi:10.1111/all. 13035 
57. Navarini AA, Satoh TK, French LE (2016) Neutrophilic dermatoses and autoinflammatory diseases with skin involvement-innate immune disorders. Semin Immunopathol 38:45-56. doi:10. 1007/s00281-015-0549-6

58. Webb K, Hlela C, Jordaan HF, Suliman S, Scriba T, Lipsker D, Scott C (2015) A review and proposed approach to the neutrophilic dermatoses of childhood. Pediatr Dermatol 32:437-446. doi:10. 1111/pde.12502

59. de Graauw E, Beltraminelli H, Simon HU, Simon D (2015) Eosinophilia in dermatologic disorders. Immunol Allergy Clin N Am 35:545-560. doi:10.1016/j.iac.2015.05.005

60. Landolt B, Staubli G, Lips U, Weibel L (2013) Skin disorders encountered in a Swiss pediatric emergency department. Swiss Med Wkly 143:w13731. doi:10.4414/smw.2013.13731

61. Demoly P, Adkinson NF, Brockow K, Castells M, Chiriac AM, Greenberger PA, Khan DA, Lang DM, Park HS, Pichler W, Sanchez-Borges M, Shiohara T, Thong BY (2014) International consensus on drug allergy. Allergy 69:420-437. doi:10.1111/all. 12350

62. Taylor D, Pappo E, Aronson IK (2016) Polymorphic eruption of pregnancy. Clin Dermatol 34:383-391. doi:10.1016/j. clindermatol.2016.02.011

63. Bork K (2014) Angioedema. Immunol Allergy Clin N Am $34: 23-$

31. doi:10.1016/j.iac.2013.09.004

64. Beltrami L, Zanichelli A, Zingale L, Vacchini R, Carugo S, Cicardi M (2011) Long-term follow-up of 111 patients with angiotensin-converting enzyme inhibitor-related angioedema. J Hypertens 29:2273-2277. doi:10.1097/HJH.0b013e32834b4b9b

65. Simons FE, Ebisawa M, Sanchez-Borges M,Thong BY, Worm M, Tanno LK, Lockey RF, El-Gamal YM, Brown SG, Park HS, Sheikh A (2015) 2015 update of the evidence base: World Allergy Organization anaphylaxis guidelines. World Allergy Organ J 8:32. doi:10.1186/s40413-015-0080-1

66. Renaudin JM, Beaudouin E, Ponvert C, Demoly P, MoneretVautrin DA (2013) Severe drug-induced anaphylaxis: analysis of 333 cases recorded by the Allergy Vigilance Network from 2002 to 2010. Allergy 68:929-937. doi:10.1111/all.12168

67. Kowalski ML, Woessner K, Sanak M. (2015) Approaches to the diagnosis and management of patients with a history of nonsteroidal anti-inflammatory drug-related urticaria and angioedema. J Allergy Clin Immunol 136:245-251. doi: 10.1016/j.jaci.2015.06. 021

68. ValentP, Akin C, Hartmann K, Nilsson G et al (2017) Advances in the classification and treatment of mastocytosis: current status and outlook toward the future. Cancer Res 77:1261-1270. doi:10. 1158/0008-5472

69. Maurer M, Church MK, Marsland AM, Sussman G, Siebenhaar F, Vestergaard C, Broom B (2016) Questions and answers in chronic urticaria: where do we stand and where do we go? J Eur Acad Dermatol Venereol 30:7-15. doi:10.1111/jdv.13695

70. WernerssonS, Pejler G (2014) Mast cell secretory granules: armed for battle. Nat Rev Immunol 14:478-494. doi:10.1038/nri3690

71. Kaplan AP,

Horáková Z,KatzSI(1978)Assessmentoftissuefluid histamine levels in patients with urticaria. J Allergy Clin Immunol 61:350-354. doi:10.1016/0091-6749(78)90113-6
72. Hong GU, Ro JY, Bae Y, Kwon IH, Park GH, Choi YH, Choi JH (2016) Association of TG2 from mast cells and chronic spontaneous urticaria pathogenesis. Ann Allergy Asthma Immunol 117: 290-297. doi:10.1016/j.anai.2016.06.026

73. Kay AB, Clark P, Maurer M, Ying S (2015) Elevations in Thelper-2-initiating cytokines (interleukin-33, interleukin-25 and thymic stromal lymphopoietin)inlesionalskinfrom chronic spontaneous ('idiopathic') urticaria. Br J Dermatol 172:12941302. doi:10.1111/bjd.13621

74. Ying S, Kikuchi Y, Meng Q, Kay AB, Kaplan AP (2002) TH1/ TH2 cytokines and inflammatory cells in skin biopsy specimens from patients with chronic idiopathic urticaria: comparison with the allergen-induced late-phase cutaneous reaction. J Allergy Clin Immunol 109:694-700

75. Altrichter S, Koch K, Church MK, Maurer M (2016) Atopic predisposition in cholinergic urticaria patients and its implications. J Eur Acad Dermatol Venereol 30:2060-2065. doi:10.1111/jdv. 13765

76. Tedeschi A, Asero R, Marzano AVet al (2009) Plasma levels and skin-eosinophil-expression of vascular endothelial growth factor in patients with chronic urticaria. Allergy 64:16161622. doi:10. 1111/j.1398-9995.2009.02069.x

77. Tedeschi A, Asero R, Lorini M et al (2010) Plasma levels of matrix metalloproteinase-9 in chronic urticaria patients correlate with disease severity and C-reactive protein but not with circulating histamine-releasing factors. Clin Exp Allergy 40:875-881. doi:10.1111/j.1365-2222.2010.03473.x

78. Kasperska-Zajac A, Sztylc J, Machura E et al (2011) Plasma IL-6 concentration correlates withclinical disease activity and serumCreactive protein concentration in chronic urticaria patients. Clin Exp Allergy 41:1386-1391. doi:10.1111/j.13652222.2011. 03789.x

79. Kaplan AP, Giménez-Arnau AM, Saini SS (2017) Mechanisms of action that contribute to efficacy of omalizumab in chronic spontaneous urticarial. Allergy 72:519-533. doi:10.1111/all.13083

80. Oliver ET, Sterba PM, Saini SS (2015) Interval shifts in basophil measures correlate with disease activity in chronic spontaneous urticaria. Allergy 70:601-603. doi:10.1111/all.12578

81. Oliver ET, Sterba PM, Devine K, Vonakis BM, Saini SS (2016) Altered expression of chemoattractant receptorhomologous molecule expressed on $\mathrm{TH} 2$ cells on blood basophils and eosinophils in patients with chronic spontaneous urticaria. J Allergy Clin Immunol 137:304-306. doi:10.1016/j.jaci.2015.06.004

82. Raap U, Gehring M, Kleiner S, Rüdrich U, Eiz-Vesper B, Haas H, Kapp A, Gibbs BF (2017) Human basophils are differentially activated by and are a source of IL-31. Clin Exp Allergy 47: 499-508. doi:10.1111/cea.12875

83. Chen Q, Zhai Z, Xu J, Chen W, Chen S, Zhong H, Huang X, Hao F, Song Z (2017) Basophil CD63 expression in chronic spontaneous urticaria: correlation with allergic sensitization, serum autoreactivity and basophil reactivity. J Eur Acad Dermatol Venereol 31:463-468. doi:10.1111/jdv.13912

84. Jain S (2014) Pathogenesis of chronic urticarial: an overview. Dermatol Res Pract 2014:674709.doi 10.1155/2014/674709

85. Sterba PM, Hamilton RG, Saini SS (2015) Suppression of basophil FceRI activation by serum from active chronic idiopathic/ spontaneous urticaria (CIU/CSU) subjects. J Invest Dermatol 135:1454-1456. doi:10.1038/jid.2015.13 
86. Kay AB, Ying S, Ardelean E, Mlynek A, Kita H, Clark P, Maurer M (2014) Elevations invascular markers andeosinophils inchronic spontaneous urticarial weals with low-level persistence in uninvolved skin. $\mathrm{Br} \mathrm{J}$ Dermatol 171:505-511. doi:10.1111/cea.12348

87. Fujisawa D, Kashiwakura J, Kita H, Kikukawa Y, Fujitani Y, Sasaki-Sakamoto T, Kuroda K, Nunomura S, Hayama K, Terui T, Ra C, Okayama Y (2014) Expression of Mas-related gene $\mathrm{X} 2$ on mast cells is upregulated in the skin of patients with severe chronic urticaria. J Allergy Clin Immunol 134:622-633. doi:10. 1016/j.jaci.2014.05.004

88. Cugno M, MarzanoAV, Tedeschi A, Fanoni D, VenegoniL, Asero R (2009) Expression of tissue factor by eosinophils in patients with chronic urticaria. Int Arch Allergy Clin Immunol 148:170- 174. doi:10.1159/000155748

89. Fiebiger E, Maurer D, Holub H, Reininger B, Hartmann G, Woisetschläger M, Kinet JP, Stingl G (1995) Serum IgG autoantibodies directed against the alpha chain of Fc epsilon RI: a selective marker and pathogenetic factor for a distinct subset of chronic urticaria patients? J Clin Invest 96:26061262

90. Kikuchi Y, Kaplan AP (2002) A role for C5a in augmenting IgGdependent histamine release from basophils in chronic urticaria. J Allergy Clin Immunol 109:114-118

91. Lu T, Jiao X, Si M, He P, Zou J, Zhang S, Zeng K (2016) The correlation of serums CCL11, CCL17, CCL26, and CCL27 and disease severity in patients with urticaria. Dis Markers 1381760. doi:10.1155/2016/1381760

92. Vonakis BM, Vasagar K, Gibbons SP Jr, Gober L, Sterba PM, Chang H, Saini SS (2007) Basophil FceRI histamine release parallels expression of Src-homology 2-containing inositol phosphatases in chronic idiopathic urticaria. J Allergy Clin Immunol 119: 441-448

93. Ayuso P, Plaza-Serón Mdel C, Blanca-López N, Doña I, Campo P, Canto G, Laguna JJ, Bartra J, Soriano-Gomis V, Blanca M, Cornejo-García JA, Perkins JR (2015) Genetic variants in arachidonic acid pathway genes associated with NSAID-exacerbated respiratory disease. Pharmacogenomics 16:825-839. doi:10. 2217/pgs.15.43

94. Asero R,TedeschiA,Coppola R,Griffini S, PaparellaP, Riboldi P, Marzano AV, Fanoni D, Cugno M (2007) Activation of the tissue factor pathway of blood coagulation in patients with chronic urticaria. J Allergy Clin Immunol 119:705-710

95. Asero R, Tedeschi A, Riboldi P, Griffini S, Bonanni E, Cugno M (2008) Severe chronic urticaria is associated with elevated plasma levels of D-dimer. Allergy 63:176-180

96. Takahagi S, Mihara S, Iwamoto K, Morioke S, Okabe T, Kameyoshi Y, Hide M (2010) Coagulation/fibrinolysis and inflammation markers are associated with disease activity in patients with chronic urticaria. Allergy 65:649-656. doi:10.1111/j. 1398-9995.2009.02222.x

97. Puccetti A, Bason C, Simeoni ME, Millo E, Tinazzi E, Beri R, Peterlana D, Zanoni G, Senna G, Corrocher R, Lunardi C (2005) In chronic idiopathic urticaria autoantibodies against Fc epsilonRII/CD23 induce histamine release via eosinophil activation. Clin Exp Allergy 35:1599-1607

98. Bossi F, Frossi B, Radillo O, Cugno M, Tedeschi A, Riboldi P, Asero R, Tedesco F, Pucillo C (2011) Mast cells are critically involved in serum-mediated vascular leakage in chronic urticaria beyond high-affinity $\operatorname{IgE}$ receptor stimulation. Allergy 66:1538- 1545. doi:10.1111/j.13989995.2011.02704.x

99. Krause K, Giménez-Arnau A, Martinez-Escala E FarréAlbadalejo M, Abajian M, Church MK, Maurer M (2013)

Platelet-activating factor (PAF) induces wheal and flare skin reactions independent of mast cell degranulation. Allergy 68:256-258. doi:10.1111/all.12083

100. Tokura Y (2016) New etiology of cholinergic urticaria. Curr Probl Dermatol 51:94-100. doi:10.1159/000446787

101. Pan XF, Gu JQ, Shan ZY (2015) The prevalence of thyroid autoimmunity in patients with urticaria: a systematic review and metaanalysis. Endocrine48:804-810.doi:10.1007/s12020014-0367-y

102. Kikuchi Y, Fann T, Kaplan AP (2003) Antithyroid antibodies in chronic urticaria and angioedema. J Allergy Clin Immunol 112: 218

103. Altrichter S, Peter HJ, Pisarevskaja D, Metz M, Martus P, Maurer M (2011) IgE mediated autoallergy against thyroid peroxidase-a novel pathomechanism of chronic spontaneous urticaria? PLoS One 6(4):e14794. doi:10.1371/journal.pone.0014794

104. Curth HM, Dinter J, Nigemeier K, Kütting F, Hunzelmann N, Steffen HM (2015) Effects of helicobacter pylori eradication in chronic spontaneous urticaria: results from a retrospective cohort study. Am J Clin Dermatol 16:553-558. doi:10.1007/s40257-015-

0152-6

105. Dreyfus DH (2016) Serological evidence that activation of ubiquitous human herpesvirus-6 (HHV-6) plays a role in chronic idiopathic/spontaneous urticaria (CIU). Clin Exp Immunol 183: 230-238. doi:10.1111/cei.12704

106. Kolkhir P, Balakirski G, Merk HF, Olisova O, Maurer M (2016) Chronic spontaneous urticaria and internal parasites-a systematic review. Allergy 71:308-322. doi:10.1111/all.12818

107. Bakker RA, Wieland K, Timmerman H, Leurs R (2000) Constitutive activity of the histamine $\mathrm{H}(1)$ receptor reveals inverse agonism of histamine $\mathrm{H}(1)$ receptor antagonists. Eur J Pharmacol 387:5-7

108. Weller K, Ziege C, Staubach P, Brockow K, Siebenhaar F, Krause K, Altrichter S, Church MK, Maurer M (2011) H1antihistamine up-dosing in chronic spontaneous urticaria: patients' perspective of effectiveness and side effects-a retrospective survey study. PLoS One 6:e23931. doi:10.1371/journal.pone.0023931

109. Krause K, Spohr A, Zuberbier T, Church MK, Maurer M (2013) Up-dosing with bilastine results in improved effectiveness in cold contact urticaria. Allergy 68:921-928. doi:10.1111/all.12171

110. Staevska M, Gugutkova M, Lazarova C, Kralimarkova T, Dimitrov V, Zuberbier T, Church MK, Popov TA (2014) NighttimesedatingH1-antihistamine increases daytime somnolence but not treatment efficacy in chronic spontaneous urticaria: a randomizedcontrolled trial. BrJ Dermatol171:148154.doi:10.1111/bjd. 12846

111. Maurer M, Rosén K, Hsieh HJ, Saini S, Grattan C, GimenézArnau A, Agarwal S, Doyle R, Canvin J, Kaplan A, Casale T (2013) Omalizumab for the treatment of chronic idiopathic or spontaneous urticaria. N Engl J Med 368:924935. doi:10.1056/ NEJMoa1215372 
112. Aubin F, Avenel-Audran M, Jeanmougin M, Adamski H, Peyron JL, Marguery MC, Léonard F, Puyraveau M, Viguier M; Société Française de Photodermatologie (2016) Omalizumab in patients with severe and refractory solar urticaria: a phase II multicentric study. J Am Acad Dermatol 74:574-575. doi: 10.1016/j.jaad. 2015.11.021

113. Chicharro P, Rodríguez P, de Argila D (2016) Omalizumab in the treatment of chronic inducible urticaria. Actas Dermosifiliogr. doi: 10.1016/j.ad.2016.07.018

114. Kaplan A, Ferrer M, Bernstein JA, Antonova E, Trzaskoma B, Raimundo K, Rosén K, Omachi TA, Khalil S, Zazzali JL (2015) Timing and duration of omalizumab response in patients with chronic idiopathic/spontaneous urticaria. J Allergy Clin Immunol 137:474-481. doi:10.1016/j.jaci.2015.08.023

115. Maurer M, Sofen H, Ortiz B, Kianifard F, Gabriel S, Bernstein JA (2016) Positive impact of omalizumab on angioedema and quality of life in patients with refractory chronic idiopathic/spontaneous urticaria: analyses according to the presence or absence of angioedema. J Eur Acad Dermatol Venereol. doi:10.1111/jdv.14075

116. Gericke J, Metz M, Ohanyan T, Weller K, Altrichter S, Skov PS, Falkencrone S, Brand J, Kromminga A, Hawro T, Church MK, Maurer M (2016) Serum autoreactivity predicts time to response to omalizumab therapy in chronic spontaneous urticaria. J Allergy Clin Immunol 139:1059-1061. doi:10.1016/j.jaci.2016.07.047

117. Bongiorno MR, Crimi N, Corrao S, Allotta A, Arena A, Brusca I, Heffler E, Malara G, Milioto M, Pistone G, Porto M, Raia E, Valenti G (2016) Omalizumab for the treatment of chronic spontaneous urticaria in clinical practice. Ann Allergy Asthma Immunol

117:703-707. doi:10.1016/j.anai.2016.08.006

118. Metz M, Ohanyan T, Church MK, Maurer M (2014) Retreatment with omalizumabresultsinrapid remissioninchronicspontaneous and inducible urticaria. JAMA Dermatol 150:288e290. doi:10. 1016/j.jdermsci.2013.08.011

119. Sussman G, Hébert J, Barron C, Bian J, Caron-Guay RM, Laflamme S, Stern S (2014) Real-life experiences with omalizumab for the treatment of chronic urticaria. Ann Allergy Asthma Immunol 112:170-174. doi:10.1016/j.anai.2013.12.005

120. Vestergaard C, Toubi E, Maurer M, Triggiani M, BallmerWeber B, Marsland A, Ferrer M, Knulst A, Giménez-Arnau A (2017) Treatment of chronic spontaneous urticaria with an inadequate response to $\mathrm{H} 1$-antihistamines: an expert opinion. Eur J Dermatol 27:10-19. doi:10.1684/ejd.2016.2905

121. Seth S, Khan DA (2017) The comparative safety of multiple alternative agents in refractory chronic urticaria patients. J Allergy Clin Immunol Pract 5:165-170. doi:10.1016/j.jaip.2016.08.010

122. Sand FL, Thomsen SF (2015) Off-label use of TNF-alpha inhibitors in a dermatological university department: retrospective evaluation of 118 patients. Dermatol Ther 28:158-165. doi:10.1111/ dth.12222

123. Kocatürk E, Maurer M, Metz M, Grattan C (2017) Looking forward to new targeted treatments for chronic spontaneous urticaria. Clin Transl Allergy 7:1. doi:10.1186/s13601-0160139-2

124. Arm JP, Bottoli I, Skerjanec A, Floch D, Groenewegen A, Maahs S, Owen CE, Jones I, Lowe PJ (2014) Pharmacokinetics, pharmacodynamics and safety of QGE031 (ligelizumab), a novel highaffinity anti-IgE antibody, in atopic subjects. Clin Exp Allergy 44(11):1371-1385. doi:10.1111/cea.12400

125. Harris JM, Cabanski CR, Scheerens H, Samineni D, Bradley MS, Cochran C, Staubach P, Metz M, Sussman G, Maurer M (2016) A randomized trial of quilizumab in adults with refractory chronic spontaneous urticaria. J Allergy Clin Immunol 138:1730-1732. doi:10.1016/j.jaci.2016.06.023

126. Dubois EA, Rissmann R, Cohen AF (2011) Rilonacept and canakinumab. $\mathrm{Br} \mathrm{J}$ Clin Pharmacol 71(5):639-641. doi:10.1111/ j.1365-2125.2011.03958.x

127. Thorp WA, Goldner W, Meza J, Poole JA (2010) Reduced vitamin D levels in adult subjects with chronic urticaria. J Allergy Clin Immunol 126:413. doi:10.1016/j.jaci.2010.04.040 